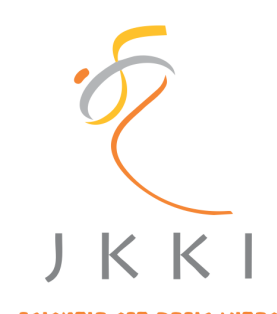

SCIENTIR EST BASIC VITAE

\section{Jurnal Kedokteran dan Kesehatan Indonesia}

\author{
Indonesian Journal of Medicine and Health
}

Journal homepage: https://journal.uii.ac.id/JKKI

\title{
Nurses' experiences in caring for dying patients: A literature review
}

Agus Ari Pratama ${ }^{1}$, Shanti Wardaningsih*2

${ }^{1}$ Sekolah Tinggi Ilmu Kesehatan (STIkes) Buleleng, Bali, Indonesia

${ }^{2}$ Master of Nursing, Universitas Muhammadiyah Yogyakarta, Indonesia,

Article Review

\begin{tabular}{l}
\hline \\
\hline A RT I L E INF O \\
\hline Keywords: \\
caring for dying patients, \\
experience, \\
nurses \\
*Corresponding author: \\
shanti.wardaningsih@umy.ac.id \\
\hline DOI:10.20885/JKKI.Vol11.Iss3.art10 \\
History: \\
Received: January 29, 2020 \\
Accepted: June 6, 2020 \\
Online: December 31, 2020 \\
\hline Copyright @2020 Authors. \\
This is an open access article \\
distributed under the terms \\
of the Creative Commons At- \\
tribution-NonCommercial 4.0 \\
International Licence (http:// \\
creativecommons.org/licences/ \\
by-nc/4.0/).
\end{tabular}

\section{ABSTRACT}

Every human will face death, and some patients can experience a critical condition during illness before death. Nurses are medical professionals who are expected to be able to care for a patient's critical condition. Studying experiences of nurses in dealing with a patient's critical condition is needed so that they can improve their services. This study aims to analyze articles that explain about nurses' experiences in dealing with dying patients. A literature review was conducted by searching articles from the PubMed and EBSCO databases (using keywords "dying AND nurse AND experience"). In the PubMed databases were found 563 articles, and in the EBSCO were found 1,632 articles. From the all the databases, only 10 articles met the inclusion and exclusion criteria. Results of the article reviews found that the experiences of nurses in caring for dying patients suggest nurses to have more empathy and to provide contextual moral encouragement for patients and their families. Nurses also need to prepare themselves with knowledge about end of life.

Setiap manusia akan menghadapi kematian, dan beberapa pasien dapat mengalami kondisi kritis saat sakit sebelum meninggal. Perawat adalah tenaga medis profesional yang diharapkan mampu merawat kondisi kritis pasien. Diperlukan kajian pengalaman perawat dalam menghadapi kondisi kritis pasien agar dapat meningkatkan pelayanannya. Penelitian ini bertujuan untuk menganalisis artikel yang menjelaskan tentang pengalaman perawat dalam menangani pasien sekarat. Sebuah tinjauan pustaka dilakukan dengan mencari artikel dari database PubMed dan EBSCO (menggunakan kata kunci "sekarat DAN perawat DAN pengalaman"). Dalam database PubMed ditemukan 563 artikel, dan di EBSCO ditemukan 1.632 artikel. Dari semua database tersebut, hanya 10 artikel yang memenuhi kriteria inklusi dan eksklusi. Hasil review artikel menemukan bahwa pengalaman perawat dalam merawat pasien sekarat memberi kesan bahwa perawat memiliki empati yang lebih dan memberikan dorongan moral kontekstual bagi pasien dan keluarganya. Perawat juga perlu mempersiapkan diri dengan pengetahuan tentang akhir hayat.

\section{INTRODUCTION}

Death is a natural process that cannot be avoided, and every human will experience it. ${ }^{1}$ Nearing death, some patients can experience a critical condition. Knowledge and attitudes of a health professional to care a patient's critical condition are needed to provide optimal health services. ${ }^{2}$ Health professionals who care for patients directly in a hospital need to be prepared to face a condition of terminal patients. Besides, they also need to understand that fear is a consequence they may experience. ${ }^{3,4}$ Nurses are health professionals who have a longer contact time together with 
patients than other medical professionals. ${ }^{5}$ This fact requires nurses to be professional and adaptive to all condition experienced by patients, including terminally ill patients who will experience a process of death. ${ }^{6}$

Holistic care needs to be provided by paying attention to various aspects of the patients. These include physical, emotional, social, economic and spiritual needs and health as external causes of death and morbidity. ${ }^{7}$ Care for terminal patients is very important, and a hospital needs to improve its nursing service. ${ }^{8}$ The nurses have to anticipate some changes of the patients whether they are in recovery or in terminal condition. Dealing with terminal patients, the nurses are suggested to learn and identify processes and signs of death of their patients. ${ }^{10,11}$ Therefore, regarding the nurses' care for the patients, this study is to provide an overview of nurses' experiences in dealing with dying patients.

\section{METHODS}

Articles chosen in this study were collected from accredited article sites such as Pubmed (www.ncbi.nlm.nih.gov/pubmed) and EBSCO (www.ebsco.com) with keywords "Dying AND Nurse AND Experience". From the both sites, 2,195 articles were obtained (563 articles from PubMed and 1,632 articles from EBSCO). Next, selections of the found articles was conducted by adjusting the inclusion criteria, including English only articles ranging from 2017 to 2018. At this stage, 24 suitable texts were found; however, after adjusting to the exclusion criteria (manuscripts in full text), there were only 10 articles acquired (Figure 1).

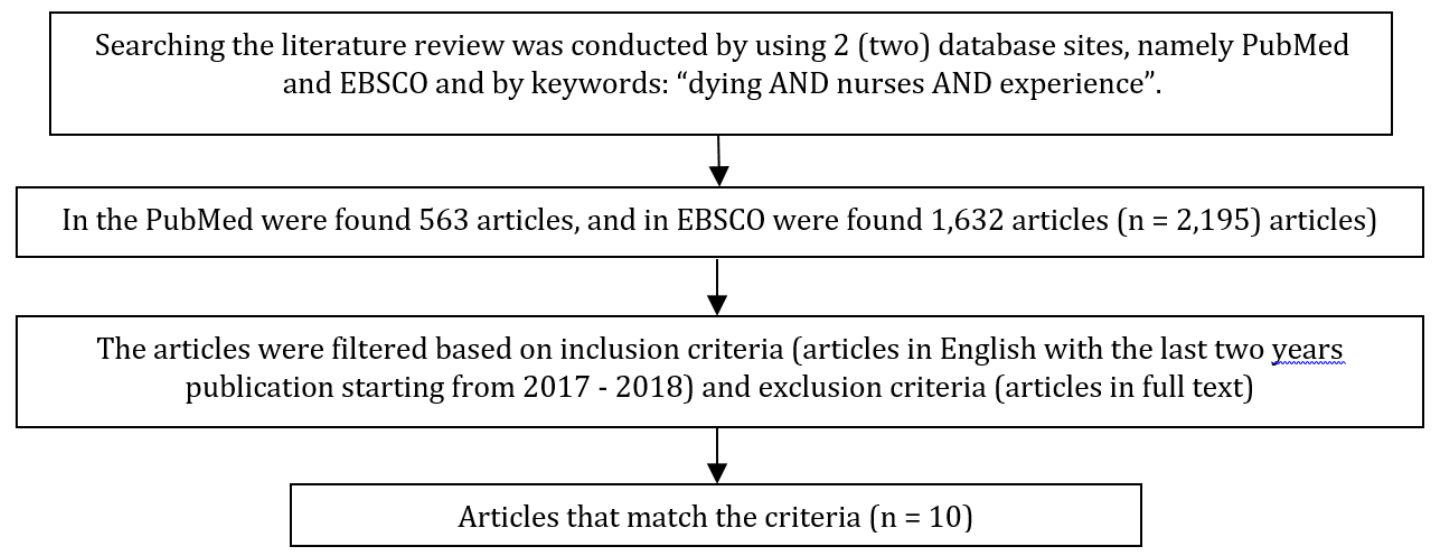

Figure 1. Article selection process

\section{RESULTS}

Of the 10 articles, there were 5 articles with qualitative designs and 5 articles with quantitative designs. The selected articles appear to represent several continents from Europe, Asia, Australia and America. From this literature study, it was found that nurses need to increase knowledge about care for dying patients and SOP in order to work professionally. ${ }^{3,4,6,9,10}$ Nurses also need to increase their sense of empathy in dealing with conditions of terminal patients. ${ }^{5}$ Collaboration between health professionals is needed to determine continuation of care and medical treatment of patients either at the hospital or at home (home care). ${ }^{2}$ Therapeutic relationships and communication between nurses, patients and families are needed to overcome denial, anger, bargaining and depression. . $^{1,2,8,11}$ 
Table 1.Data of qualitative articles about nurses' experiences in dealing with critical patients.

\begin{tabular}{ccll}
\hline No. & \multicolumn{1}{c}{ Title } & \multicolumn{1}{c}{ Nurses' Experiences } & Problems experienced nurses \\
\hline 1 & Lived experiences of grief & Meanings of the experience of grief & Sadness can affect emotion, \\
of Muslim nurses caring & experienced by Muslim nurses in the & cognition, spirituality, relationship, \\
for patients who died in & ICU are as below: & and professionalism of nurses in \\
an intensive care unit: & 1. Understanding a sense of empathy. & dealing with critical patients in \\
A phenomenological & 2. Understanding positioning of self. & the future. \\
study. & 3. Anticipating from grieving. & \\
& 4. Imagining about the death that will \\
& happen to the patient.
\end{tabular}

2 The Lived Experiences of Experiences that arise from caring Nurses Caring for Dying for critical pediatric patients include: Pediatric Patients. ${ }^{8}$

1. Empathy, feelings of uncertainty,

Nurses experience deep emotions when dealing with a dying and hope.

2. Getting inspiration.

3. Fostering a sense of care.

4. Professionalism in providing nursing care.

5. Emergence of sadness.

3 Nurses' Experiences of The nurses experience feelings like: Grief Following Patient 1. sadness which is characterized by Death. ${ }^{5}$

crying, anger, shock, rejection, fear and guilt that persist after a patient death. pediatric patient. 2. helplessness for a patient's family reaction.

4 Nurses' perceptions and Some of the nurses' perceptions after experiences of caring for facing the patient's death include: patients who die in the 1. End-of-life care is part of treatments emergency department for patients with critical conditions. setting. ${ }^{10}$

2. Occurrences of implementation problems during end-of-life care.

3. Lack of end-of-life education.

4. Unclear roles of nurses in end-oflife care.

5. Occurrences of emotional effects.

5 Exploring nurses' end- Dealing with critical patients, nurses of-life care for dying need to prepare themselves to face patients in the ICU using changes of the patients' condition focus group interviews. ${ }^{9}$ because they directly accompany the

The nurses' emotional feelings about death can affect how to care for other patients.

patients. The need for nurses to be

Lack of training for the end-oflife care will lead to problems for nurses to provide qualified service for a critical patient.

well prepared for the intensive care unit.

Notes: 1-4: semi-structured interview, 5: semi- structured interviews and focus group discussion (FGD) 
Table 2. Table of quantitative data about nurses' experiences in dealing with critical patients.

\begin{tabular}{|c|c|c|c|}
\hline No. & Title & Experiences faced by nurses & Constraints faced by nurses \\
\hline 1 & $\begin{array}{l}\text { Facing death in the clinical } \\
\text { practice: a view from } \\
\text { nurses in Mexico. }{ }^{4}\end{array}$ & $\begin{array}{l}\text { Patients in critical condition must } \\
\text { know the prognoses of their diseases } \\
\text { (one of which is death). }\end{array}$ & $\begin{array}{l}\text { Doctors often delegate informed } \\
\text { consent for patients (related to } \\
\text { prognoses of their disease) to } \\
\text { nurses. }\end{array}$ \\
\hline 2 & $\begin{array}{l}\text { Nurses attitudes towards } \\
\text { death, dying patients and } \\
\text { euthanasia: A descriptive } \\
\text { study. }^{2}\end{array}$ & $\begin{array}{l}\text { Nurse considers death as a terminal- } \\
\text { phase patient. They are less aware of } \\
\text { views of patients facing euthanasia. }\end{array}$ & $\begin{array}{l}\text { Emotional disturbances and } \\
\text { decreased job satisfaction } \\
\text { can arise in nurses who care } \\
\text { for critically ill patients with } \\
\text { euthanasia. }\end{array}$ \\
\hline 3 & $\begin{array}{l}\text { Nurses' experience with } \\
\text { relatives of patients } \\
\text { receiving end of life care } \\
\text { in nursing homes and at } \\
\text { home: A questionnaire- } \\
\text { based cross-sectional } \\
\text { study. }^{3}\end{array}$ & $\begin{array}{l}\text { Home care nurses often face and } \\
\text { communicate with patient's family. } \\
\text { They are uncomfortable about the } \\
\text { patient's desire for lifelong treatment. }\end{array}$ & $\begin{array}{l}\text { In home care nursing, there } \\
\text { is no collaboration between } \\
\text { nurses and doctors because of } \\
\text { the service cost. It is also caused } \\
\text { by problems of organizational } \\
\text { structures, economy and culture } \\
\text { in primary health cares. }\end{array}$ \\
\hline 4 & $\begin{array}{l}\text { Clinical nurses' attitudes } \\
\text { towards death and caring } \\
\text { for dying patients in } \\
\text { China. }{ }^{1}\end{array}$ & $\begin{array}{l}\text { Clinical nurses in China pay sufficient } \\
\text { attention to critical patients' families, } \\
\text { but not to the patients. Nurses do not } \\
\text { have positive attitudes and sufficient } \\
\text { communication skills to serve } \\
\text { the patients. They also have poor } \\
\text { judgment when it comes to avoiding } \\
\text { patient deaths. }\end{array}$ & $\begin{array}{l}\text { Education levels, fear of } \\
\text { death, religious beliefs, and } \\
\text { experiences of nurses in dealing } \\
\text { with critical patients until death } \\
\text { can affect their attitudes in } \\
\text { caring for critical patients. }\end{array}$ \\
\hline 5 & $\begin{array}{l}\text { A Questionnaire Study } \\
\text { on the Attitude towards } \\
\text { Death of the Nursing } \\
\text { Interns in Eight Teaching } \\
\text { Hospitals in Jiangsu, } \\
\text { China. }^{11}\end{array}$ & $\begin{array}{l}\text { Attitudes of nurses are influenced by } \\
\text { education levels, fear of facing the } \\
\text { patient's death, religious differences } \\
\text { between the nurse and the patient, } \\
\text { and previous knowledge of near death } \\
\text { to death. }\end{array}$ & $\begin{array}{l}\text { Among the nurses, there were } \\
\text { differences of attitudes for death } \\
\text { or caring for critical patients. } \\
\text { The differences are based on } \\
\text { society, ethnicity, education, } \\
\text { socio-economic condition and } \\
\text { religious differences. }\end{array}$ \\
\hline
\end{tabular}

\section{DISCUSSION}

Feelings experienced by nurses in dealing with dying patients include emergences of empathy and deeply emotional sadness. ${ }^{5,6}$ These experiences were faced by nurses who reject a thought about death which eventually may affect a quality care of the patients' end of life. Nurses must view the patients as complete human beings, who are living and welcoming the death. Therefore, nurses need to know about the end of life and signs of near-death to death. ${ }^{7,10}$ Nurses as a health care provider feel that patients who are critically ill need to get sufficient information regarding the near- death event. ${ }^{8.9}$ Consequently, establishing good communication with the patients and their family is compulsory. ${ }^{1}$ Nurses must also have positive attitudes although they have different opinions with the patients and their families. ${ }^{11}$

Nursing care must meet the patients' physical, emotional, intellectual, social and spiritual needs. ${ }^{1}$ Therefore, nurses need to have basic nursing knowledge and nursing skills. Besides, they need to have other related knowledge such as interpersonal relationship skills, psychology, human growth and development, communication skills and sociology. Their attitudes in dealing with patients who face 
death is very important. Nurses can act as a facilitator by involving the family to support the patient care. ${ }^{15}$ They also play an important role in providing spiritual guidance to the patients to fulfill biopsychososiospiritual needs of patients. $^{3}$

Holistic care is significant for nurses, especially in caring for the terminal patients to improve the patient's quality of life. ${ }^{16}$ This can be conducted by reducing pain or overcoming other complaints from the patients. Nurses also have to meet physiological needs of the patients because the terminally ill patients have very high dependence on other people to take care and provide comfort. ${ }^{6,14}$ Besides, they need to maintain psychological and spiritual balance of the patients and keep them active until the end of their life. Furthermore, overcoming grief for the family is one of difficult tasks to perform by the nurses. ${ }^{5}$ Complete assistance given to dying patients is part of nursing care at the end of life to support comfort for the patients. Those difficult duties can only be done with ability, willingness or knowledge in providing good and holistic nursing care for patients. ${ }^{12}$

\section{CONCLUSION}

Exploring the experiences of nurses in dealing with dying patients can provide overviews for nurses to have more empathy and to provide contextual moral encouragement to the patients and their families. Nurses also need to prepare themselves with knowledge about end of life.

\section{CONFLICT OF INTEREST}

There is no conflict of interest.

\section{ACKNOWLEDGEMENT}

The authors thank to the Department of Master of Nursing at Universitas Muhammadiyah Yogyakarta as a place for the author to study nursing and Sekolah Tinggi Ilmu Kesehatan (STIkes) Buleleng where the authors work and that provides scholarship to support studying at the university.

\section{REFERENCES}

1. Wang L, Li C, Zhang Q, Li Y. Clinical nurses' attitudes towards death and caring for dying patients in China. International Journal of Palliative Nursing. 2018;24(1):33-9.

2. Ay MA, Öz F. Nurses attitudes towards death, dying patients and euthanasia: A descriptive study. Nursing Ethics. 2019;26(5):1442-57.

3. Paulsen B, Johnsen R, Hadders H. Nurses' experience with relatives of patients receiving end-of-life care in nursing homes and at home: A questionnaire-based cross-sectional study. Nursing Open. 2018;5(3):43141.

4. Marván ML, Oñate-Ocaña LF, Santillán-Doherty $\mathrm{P}$, Álvarez-del Río A. Facing death in the clinical practice: A view from nurses in Mexico. Salud Publica de Mexico. 2017;59(6):675-81.

5. Khalaf I, Al-Dweik G, Abu-Snieneh H, Al-Daken L, Musallam R, BaniYounis $\mathrm{M}$, et al. Nurses' Experiences of Grief Following Patient Death. Vol. XX, Journal of Holistic Nursing. 2017. 1-13 p.

6. Betriana F, Kongsuwan W. Lived experiences of grief of Muslim nurses caring for patients who died in an intensive care unit: A phenomenological study. Intensive and Critical Care Nursing. 2019;52:9-16.

7. Jasarevic T. World Health Assembly Update [Internet]. 2019 [cited 2019 Dec 21]. Available from: https://www.who.int/newsroom/detail/22-05-2019-world-health-assembly-72-update

8. Curcio DL. The lived experiences of nurses caring for dying pediatric patients. Pediatric Nursing. 2017;43(1):8-14.

9. Jang SK, Park WH, Kim HI, Chang SO. Exploring nurses' end-of-life care for dying patients in the ICU using focus group interviews. Intensive and Critical Care Nursing. 2019;52:3-8.

10. Giles TM, Hammad K, Breaden K, Drummond C, Bradley SL, Gerace A, et al. Nurses' perceptions and experiences of caring for patients who die in the emergency department setting. International Emergency Nursing. 2019;47.

11. Xu F, Huang K, Wang Y, Xu Y, Ma L, Cao Y. 
A Questionnaire Study on the Attitude towards Death of the Nursing Interns in Eight Teaching Hospitals in Jiangsu, China. BioMed Research International. 2019;2019:1-8.

12. Alligood MR. Nursing theorists and their work 8th Edition. Elsevier; 2014.

13. Ferrell B, Coyle N, Paice JA. Oxford textbook of palliative nursing (4th edition). 2015.

14. Wilkinson AM, Witt Sherman D, Metheny T, Matzo M, Witt Sherman D, Bookbinder M, et al. Palliative Care Nursing. 5th ed. Matzo M, Sherman W, editors. Quality Care to the End of Life. New York: Springer Publishing Company;

15. Rosser M, Walsh H. Fundamentals of Palliative Care for Student Nurses. 2014. 305 p.

16. Snowden A, Donnell A, Duffy T. Pioneering Theories in Nursing. 2014. 